ISSN: 2362-1303 (Paper) | eISSN: 2362-1311(Online)

JOURNAL OF ADVANCED ACADEMIC RESEARCH (JAAR)

January 2015

\title{
Media and Advertising Preferences of Nepalese Audiences
}

\section{Gopal Thapa ${ }^{1}$}

${ }^{1}$ Lecturer, Nepal Commerce Campus (TU), Minbhawan, Kathmandu

${ }^{1} \mathrm{PhD}$ Scholar, Dr. K N Modi University, Rajasthan, India

Under the Supervision of Prof. Dr. Bihari Binod Pokharel

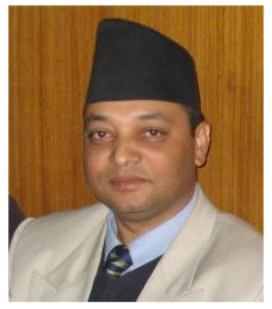

\begin{abstract}
No one can escape from death, tax and advertising. There are various media available for advertising. Advertising is used by different organization in different ways. Different customers have responded differently, to the different message and media. This article highlights on the consumers' preference towards the message and media on the basis of age, gender and education. This study is part of the pilot study of my $\mathrm{PhD}$ research work. It is a descriptive study based on survey method. Total 80 respondents consisting different gender, age and education background were taken as sample on judgmental basis. The result revealed that most of the Nepalese prefer television, television advertising and musical message.
\end{abstract}

Keywords: Advertisement, Audience, Consumer, Media television,

\section{Introduction}

\section{Advertising}

One of the popular tools of marketing communication is advertising. Advertising is any paid form of non-personal presentation and promotion of ideas, goods or services by an identified sponsor. Advertising is used by different organization in different ways. A large company set up its own advertising department for all or most of the advertising functions while those do not have separate department hires advertising agencies to promote their products. There are various types of media are available in the market for advertisers to conduct advertising functions.

\section{Television Advertising}

Among various media television is one which hold upper hand because of its unique audio and visual characteristics. According to Keller (2008), Television is generally acknowledged as the most powerful advertising medium as it allows for sight, sound, and motion and reaches a broad spectrum of consumers. The wide reach of TV advertising translates to low cost per exposure. From a brand equity perspective, TV advertising has two particularly important strengths. First, 
ISSN: 2362-1303 (Paper) | eISSN: 2362-1311(Online)

JOURNAL OF ADVANCED ACADEMIC RESEARCH (JAAR)

January 2015

TV advertising can be effective means of vividly demonstrating product attributes and persuasively explaining their corresponding consumer benefits. Second, TV advertising can be compelling means for dramatically portraying non-product-related user and usage imagery, brand personality, and so on. Television is a common medium of information and is very effective in delivering a message or in a wide sense, for effective marketing communication. Kotler \& Fox (1985) stated that television has advantages and disadvantages related to its effectiveness as a medium to broadcast advertising messages. The advantages are that the information can be easily viewed, listened to, and pictured. Belch \& Belch (2004) stated that television is considered the ideal medium to advertise as advertisement exposure can showcase the most attractive side of the products. The disadvantage of TV advertising is the higher cost, that fact that it can be highly confusing medium that the audience is selective. In emerging market like Nepal, television is the most popular medium for information and entertainment

A television advertisement is a span of television programming produced and paid for by an organization that conveys a message fully controlled by an advertiser. Television advertising is also popularly known as television commercials. Television advertisement gives information to a large number of people than any other medium, comparatively at lower cost per audience. Due to its satellite facility, television programs are viewed globally. In today's glamorous world, we can show all aspects of products, services or organizations through advertisement with human appeal. The vast majority of television advertisements today consist of brief advertising spots, ranging in length from a few seconds to several minute infomercials. Advertisement of these sorts has been used to sell imaginable over the years, from the household products to political campaigns.

In today's world, the popularity of television is increasing day by day. It is useful for the advertisers to know the popularity of television among different people. Different types of advertisement appeal to the different customers differently. Careful analysis should be done in this regard for the success of any advertisement campaign. Hence, the main objective of this study is to provide useful information regarding the effectiveness of television advertising to different people in urban areas.

\section{$\underline{\text { Objective }}$}

Main objective of this study is to analyze the media and advertising preferred by Nepalese audience on the basis of age, education, gender etc. It also analyzes the effectiveness of message preferred by different target audiences.

\section{Method}

This study is a descriptive research based on survey method. It is based on the pilot study of my ph d work. It is based on primary data. Self administered closed ended questionnaires were 
ISSN: 2362-1303 (Paper) | eISSN: 2362-1311(Online)

JOURNAL OF ADVANCED ACADEMIC RESEARCH (JAAR)

distributed between January 20, 2012 to February 25, 2012. Data was collected from students and faculty members of various colleges under Tribhuvan University within Kathmandu valley offering business education.100 questionnaire were distributed on the basis of judgmental sampling. Among them 80 questionnaires were returned. Among the 80 respondents from the urban areas of Kathmandu valley, 40 respondents were male and 40 were female. Simple descriptive statistical tools have used to analyze the data.

\section{Result and discussion}

Among the 80 respondents, collected data from various age and education background is presented as follows:

Table No. 1: Education and age of Respondents

\begin{tabular}{|l|l|l|l|}
\hline Education Level & Sample Size & Age Group & Sample Size \\
\hline Below S. L. C. & 16 & Below 15 & 16 \\
\hline S. L. C. & 16 & $16-25$ & 16 \\
\hline Plus 2 & 16 & $26-35$ & 16 \\
\hline Graduate & 16 & $36-45$ & 16 \\
\hline Post Graduate & 16 & Above 45 & 16 \\
\hline Total & $\mathbf{8 0}$ & Total & $\mathbf{8 0}$ \\
\hline
\end{tabular}

Source: Field Survey 2012

\section{Advertising and Customers' Preference}

While taking advertising decisions, advertisers should be aware about the types of television advertisement preferred by the audiences. In this study all advertisements are divided into four categories consisting musical advertisement, glamorous advertisements, simple advertisements and all or mixed types of advertisements.

The table shows the age level and their advertisement preference.

Table No. 2: Age and Advertisement Preference

\begin{tabular}{|c|c|c|c|c|c|c|c|c|c|c|}
\hline Age & $\begin{array}{l}\text { No. of } \\
\text { Respondents }\end{array}$ & $\begin{array}{l}\text { Musi } \\
\text { cal }\end{array}$ & $\%$ & $\begin{array}{l}\text { Glamor } \\
\text { ous }\end{array}$ & $\%$ & $\begin{array}{l}\text { Simp } \\
\text { le }\end{array}$ & $\%$ & $\begin{array}{l}\text { All } \\
\text { Types }\end{array}$ & $\%$ & $\begin{array}{l}\text { Total } \\
\%\end{array}$ \\
\hline $\begin{array}{l}\text { Below } \\
15\end{array}$ & 16 & 10 & $\begin{array}{l}62 . \\
5\end{array}$ & 3 & $\begin{array}{l}18 . \\
75\end{array}$ & 1 & $\begin{array}{l}6.2 \\
5\end{array}$ & 2 & $\begin{array}{l}12 . \\
5\end{array}$ & 100 \\
\hline $16-25$ & 16 & 9 & $\begin{array}{l}56 . \\
25\end{array}$ & 5 & $\begin{array}{l}31 . \\
25\end{array}$ & 0 & 0 & 2 & $\begin{array}{l}12 . \\
5\end{array}$ & 100 \\
\hline $26-35$ & 16 & 6 & 37. & 7 & 43. & 0 & 0 & 3 & 18. & 100 \\
\hline
\end{tabular}


ISSN: 2362-1303 (Paper) | eISSN: 2362-1311(Online)

JOURNAL OF ADVANCED ACADEMIC RESEARCH (JAAR)

January 2015

\begin{tabular}{|c|c|c|c|c|c|c|c|c|c|c|}
\hline & & & 5 & & 75 & & & & 75 & \\
\hline $36-45$ & 16 & 5 & $\begin{array}{l}31 . \\
25\end{array}$ & 9 & $\begin{array}{l}56 . \\
25\end{array}$ & 1 & $\begin{array}{l}6.2 \\
5\end{array}$ & 1 & $\begin{array}{l}6.2 \\
5\end{array}$ & 100 \\
\hline $\begin{array}{l}\text { Above } \\
45\end{array}$ & 16 & 8 & 50 & 7 & $\begin{array}{l}43 . \\
75\end{array}$ & 0 & 0 & 1 & $\begin{array}{l}6.2 \\
5\end{array}$ & 100 \\
\hline Total & 80 & 38 & & 31 & & 2 & & 9 & & \\
\hline
\end{tabular}

Source: Field Survey 2012

It was found that $62.5 \%$ of people who are below 15 years, preferred musical ad mostly. Likewise, $56.25 \%$ of people who are $16-25$ years also preferred musical ad but $43.75 \%$ of the people who are 26-35years old and $56.25 \%$ of people who are 36-45 years old preferred glamorous advertising. Similarly, $50 \%$ of the people who are above 45 years old liked musical advertising.

Consumers' preferences on the basis of literacy level on Television advertising is presented in the following table.

Table No. 3: Literacy - wise Consumers' Preference on Television Advertising

\begin{tabular}{|l|l|l|l|l|l|l|l|l|l|l|}
\hline Education Level & $\begin{array}{l}\text { Sample } \\
\text { Size }\end{array}$ & $\begin{array}{l}\text { Musi } \\
\text { cal }\end{array}$ & $\mathbf{\%}$ & $\begin{array}{l}\text { Glam } \\
\text { orous }\end{array}$ & $\boldsymbol{\%}$ & Simple & \% & $\begin{array}{l}\text { All } \\
\text { Types }\end{array}$ & $\begin{array}{l}\text { Tot } \\
\text { al }\end{array}$ \\
\hline Below SLC & 16 & 11 & 68.75 & 3 & 18.75 & 1 & 6.25 & 1 & 6.25 & 16 \\
\hline SLC & 16 & 9 & 56.25 & 4 & 25 & 2 & 12.5 & 1 & 6.25 & 16 \\
\hline Plus two & 16 & 6 & 37.5 & 8 & 50 & 0 & 0 & 2 & 12.5 & 16 \\
\hline Graduate & 16 & 5 & 31.25 & 9 & 56.25 & 0 & 0 & 2 & 12.5 & 16 \\
\hline Post Graduate & 16 & 10 & 62.5 & 3 & 18.75 & 2 & 12.5 & 1 & 6.25 & 16 \\
\hline Total & $\mathbf{8 0}$ & $\mathbf{4 1}$ & 51.25 & $\mathbf{2 7}$ & 33.75 & $\mathbf{5}$ & 6.25 & $\mathbf{7}$ & 8.75 & $\mathbf{1 8 0}$ \\
\hline
\end{tabular}

Source: Field survey: 2012

The above table shows that people who belong to below SLC and SLC preferred to musical advertisement i.e. $68.75 \%$ and $56.25 \%$ respectively. Most of the plus 2 and graduate people i.e. $50 \%$ and $56.56 \%$ respectively preferred to glamorous advertisement. Again, people who belong to post graduate group preferred to musical advertisement are by $62.5 \%$.

The above table shows that plus 2 and graduate people are influenced by glamorous advertisement and below SLC, SLC and post graduate people are influenced by musical advertisement.

Likewise consumer preference on television advertisement as per the gender is presented as follows: 
ISSN: 2362-1303 (Paper) | eISSN: 2362-1311(Online)

JOURNAL OF ADVANCED ACADEMIC RESEARCH (JAAR)

Table No. 4: Gender-wise Preference of Television Advertisements

\begin{tabular}{|l|l|l|l|l|l|l|l|l|l|l|}
\hline $\begin{array}{l}\text { Gende } \\
\mathbf{r}\end{array}$ & $\begin{array}{l}\text { Sampl } \\
\text { e Size }\end{array}$ & $\begin{array}{l}\text { Musica } \\
\mathbf{l}\end{array}$ & $\mathbf{\%}$ & Glamorous & $\mathbf{\%}$ & $\begin{array}{l}\text { Simpl } \\
\text { e }\end{array}$ & \% & $\begin{array}{l}\text { All } \\
\text { Types }\end{array}$ & \% & Total \\
\hline Male & 40 & 20 & 50 & 15 & $\begin{array}{l}37 . \\
5\end{array}$ & 3 & 7.5 & 2 & 5 & 40 \\
\hline Female & 40 & 25 & 5 & 10 & 25 & 1 & 2.5 & 4 & 1 & 40 \\
\hline Total & 80 & 45 & & 25 & & 4 & & 6 & & 80 \\
\hline
\end{tabular}

Source: Field survey: 2012

The above table shows the preference of advertisement according to gender. Out of 40 male $50 \%$ of respondents are found to like the musical advertisements, $37.5 \%$ of respondents preferred to glamorous advertisements, $7.5 \%$ of respondents preferred simple advertisements and $5 \%$ respondents liked all types of advertisements. Regarding female respondents, $62.5 \%$ preferred musical advertisements, $25 \%$ preferred glamorous advertisements, $2.5 \%$ preferred simple advertisements and $10 \%$ preferred all types of advertisements.

From the above analysis, it can be concluded that female consumers seems to give more priority to musical advertisements than the glamorous advertisements. For more clarity the above information is presented in following diagram.

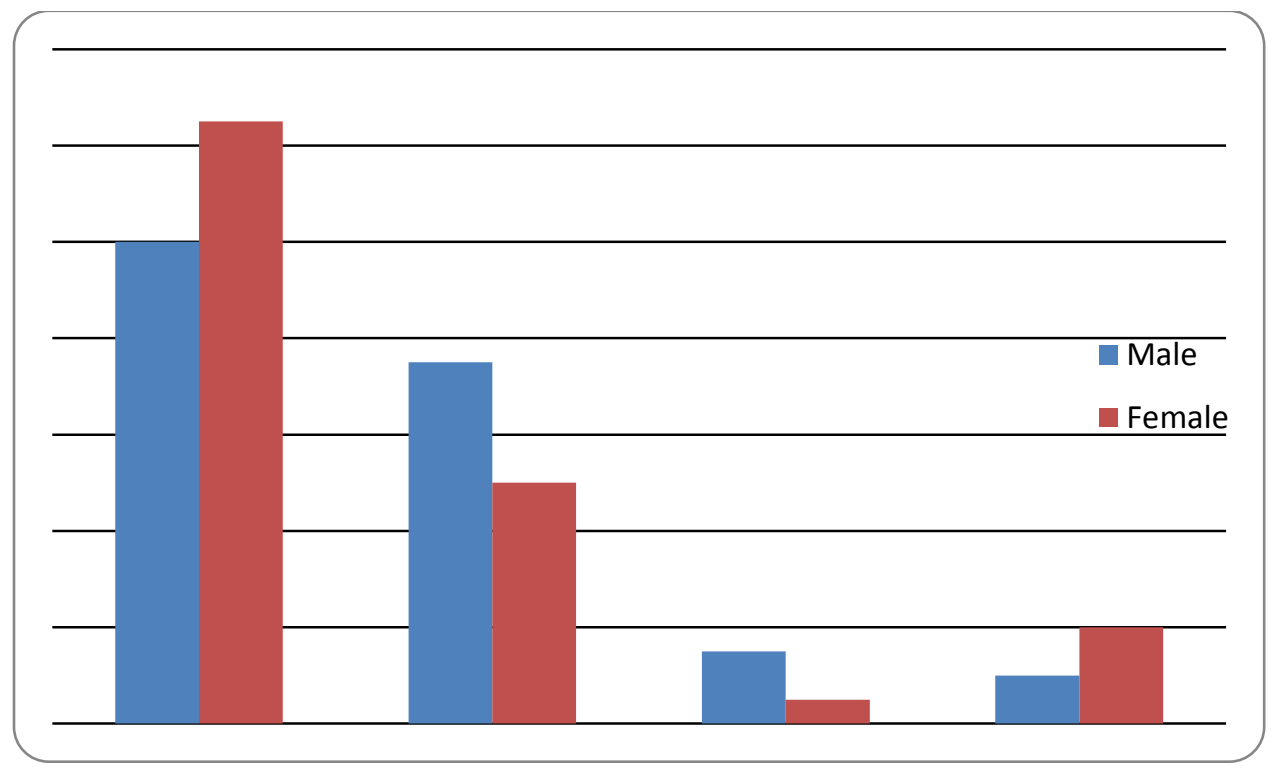

From above diagram, it is clear that out of the total 40 male respondents $50 \%$ respondents preferred to musical advertisements, 35\% preferred to glamorous advertisements, $8 \%$ preferred to simple advertisements and 5\% respondents preferred to all types of 
ISSN: 2362-1303 (Paper) | eISSN: 2362-1311(Online)

JOURNAL OF ADVANCED ACADEMIC RESEARCH (JAAR)

advertisements. Similarly, among the 40 female respondents, $62.5 \%$ preferred to musical advertisements, $25 \%$ preferred to glamorous advertisements, $2.5 \%$ referred to simple advertisements and $10 \%$ preferred to all types of advertisements.

The table below presents the consumers way of watching television when advertisements arte telecasted.

Table No. 5: Consumers Television Watching Habit

\begin{tabular}{|l|l|l|l|l|l|}
\hline Gender & Sample Size & Watching & \% & Not watching & \% \\
\hline Male & 40 & 30 & 75 & 10 & 25 \\
\hline Female & 40 & 34 & 85 & 6 & 15 \\
\hline Total & 80 & 64 & 80 & 16 & 20 \\
\hline
\end{tabular}

Source: Field survey: 2012

The above table presents the habit of people watching television living in Kathmandu. Out of total $80 \%$ people are found to have the habit of watching television. Among them, $75 \%$ male and $85 \%$ female are found that they are watching television where female percentage is higher than male by $10 \%$. Television watching habit of male and female is also explained by the following bar diagram.

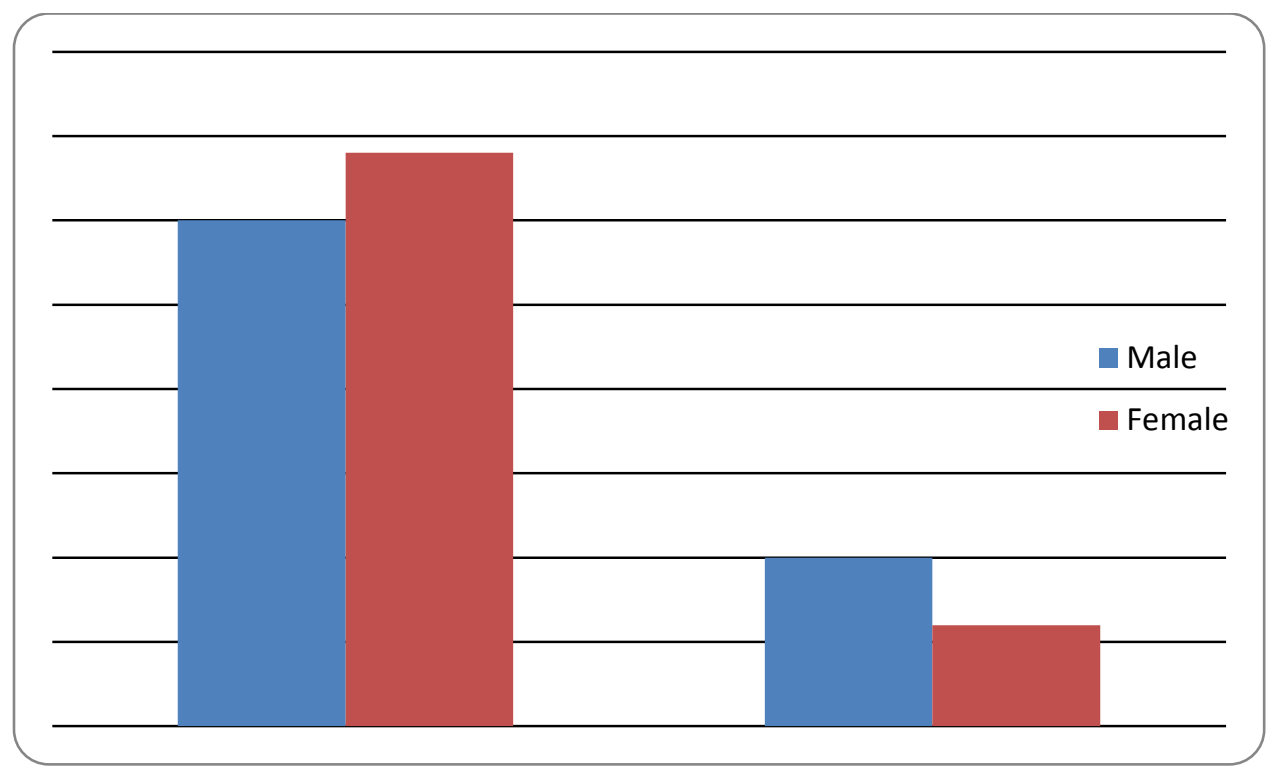

From the above figures, it is clear that percentage of women watching television seems higher than male by $10 \%$. Likewise, $25 \%$ of male are found not to have the habit of watching television whereas female percentage is only $15 \%$. 
ISSN: 2362-1303 (Paper) | eISSN: 2362-1311(Online)

JOURNAL OF ADVANCED ACADEMIC RESEARCH (JAAR)

January 2015

\section{Consumers' Preferences to the Product}

Consumer prefers different product by considering various factors. Advertisement is one of the important factors which affect the consumers' preferences. The result of consumers' preferences to the various type of product is presented in the table below:

\section{Table No. 6: Consumers' Preferences to the Product Advertised}

\begin{tabular}{|l|l|l|}
\hline Description & No. of Respondents & $\%$ \\
\hline Product frequently advertised & 65 & 81.25 \\
\hline Product not advertised & 15 & 18.75 \\
\hline Total & 80 & 100 \\
\hline
\end{tabular}

Source: Field survey: 2012

The above table shows the number of consumers' preferences to the product. Out of the 80 respondents, $81.25 \%$ responded that they prefer the frequently advertised product whereas $18.75 \%$ respondents opined that they prefer to buy the product that is not advertised.

From the above analysis, it can be concluded that majority of the consumers give the priority to the frequently advertised product.

\section{Consumers' Preferences to the Media}

Consumers prefer different media according to their needs, interests and priority. There are various media available in the market like newspaper, magazine, radio, television, pamphlets and poster etc. The situation of consumers' preferences to the various media is presented in the table below:

Table No. 7: Consumers' Preferences to the Media

\begin{tabular}{|l|l|l|}
\hline Media & No. of Respondents & $\%$ \\
\hline Newspaper & 10 & 12.5 \\
\hline Magazine & 2 & 2.5 \\
\hline Television & 63 & 78.75 \\
\hline Radio & 4 & 5 \\
\hline Pamphlets \& Posters & 1 & 1.25 \\
\hline Total & 80 & 100 \\
\hline
\end{tabular}

Source: Field Survey 2012

The above information presents the number of respondents preferring the media. Out of the total 80 respondents, majority of respondents $78.75 \%$ preferred to television whereas rest of 
ISSN: 2362-1303 (Paper) | eISSN: 2362-1311(Online)

JOURNAL OF ADVANCED ACADEMIC RESEARCH (JAAR)

January 2015

the respondents opined that they prefer Newspaper, Magazine, Radio and Pamphlets \& posters by $12.5 \%, 2.5 \%, 5 \%$ and $1.25 \%$ respectively.

From the above analysis, it can be concluded that Television advertisement seems to be the most popular media.

The present study was conducted to analyze the media and advertising preferred by Nepalese audience on the basis of age, education, gender. The result revealed that majority of the Nepalese audiences' preferred musical advertisements. This finding is in line with previous study of Bhandari (1984). Results also revealed that most of the audiences preferred to watch television. In the opinion of Agrawal and Singh (1985) nearly 70\% of Indian customers prefer to watch television. In comparison to previous findings Nepalese audiences' preference towards television is higher than Indian customer. Mittal (1994) concluded this study that $75 \%$ urban customer purchase product because of advertising. Comparing these findings to the present study, majority of the customers $(81.25 \%)$ preferred frequently advertised products which is higher than previous findings.

\section{Conclusion}

Majority of the respondents who belong to age group below 15 and 16 to 25 preferred musical advertisement by $62.5 \%$ and $56.25 \%$ respectively. In the context of age group 26 to 35 and 36 to 45 majority of the respondents preferred glamorous advertisement i.e. $43.75 \%$, and $56.25 \%$ respectively. Again age group above 45, majority of the respondents i.e. $47.5 \%$ preferred musical advertisement.

In case of education-wise preferences to the advertisement indicate that most of the lower educated preferred to musical advertisement. Likewise most of the male as well as female customers preferred musical advertisements.

In relation to television watching habits, majority of the respondents $(80 \%)$ found to have the habit of watching television. The percentage of women respondents seems to be higher than male respondents regarding television viewing habit.

Similarly, majority of the customers $(81.25 \%)$ preferred frequently advertised products.

In relation to the consumers' preference towards media, most of the respondents $(78.58 \%)$ responded that they preferred to television. Thus, television is the most popular media for advertisement. 
ISSN: 2362-1303 (Paper) | eISSN: 2362-1311(Online)

JOURNAL OF ADVANCED ACADEMIC RESEARCH (JAAR)

January 2015

\section{References}

Aaker, Batra \& Myers (1995). Advertising Management. New Delhi: Prentice Hall of India Private Limited.

Amatya, S.K. and Gopal Thapa (2005). Fundamenetals of Advertising. Kathmandu: Khanal Publication Pvt.Ltd.

Belch, Belch \& Purani (2010). Advertising and Promotion. New Delhi: Tata McGraw Hill Education Private Limited.

Clow \& Baack (2006) Integrated Advertising, Promotion and Marketing Communications. New Delhi: Prentice Hall of India Private Limited.

Chunawalla, S. A. (2010). Advertising, Sales and Promotion Management. Mumbai: Himalaya Publishing House.

Chunawalla, S. A. and R. C. Sethia (1999). Foundations of Advertising: Theory and Practice. Mumbai: Himalaya Publishing House.

Kumar \& Mittal (2002). Advertising Management. New Delhi: Anmol Publications Private Limited.

Shah \& D'Souza (2009). Advertising and Promotions an IMC perspective. New Delhi: Tata McGraw Hill Education Private Limited.

Sontakki, C. N. (1999). Advertising . Mumbai: Kalyani Publishers.

Thapa, Gopal (2008). Dictionary of Marketing. Kathmandu: Buddha Academic Enterprises Pvt. Ltd.

Thapa, Gopal and D. K. Neupane (2009). Marketing Management. Kathmandu: Ashmita Publication Pvt. Ltd.

Wofff, K Howard and Prem Raj Pant (2010). Social Science Research and Thesis Writing. Kathmandu: Buddha Academic Enterprises Pvt. Limited. 